\title{
Body dissatisfaction and sociodemographic, anthropometric and maturational factors among artistic gymnastics athletes
}

CDD. 20.ed. 796.033

796.41

http://dx.doi.org/10.1590/1807-55092016000100061

\author{
Clara Mockdece NEVES \\ Juliana Fernandes Filgueiras MEIRELES* \\ Pedro Henrique Berbert de CARVALHO ${ }^{* *}$ \\ Maria Elisa Caputo FERREIRA*
}

*Faculdade de Educação Física e Desportos, Universidade Federal de Juiz de Fora, Juiz de Fora, MG, Brasil.

${ }^{* *}$ Curso de Educação Física, Universidade Federal de Juiz de Fora, Governador Valadares, MG, Brasil.

\begin{abstract}
This study aimed to evaluate the overall body dissatisfaction and in specific areas in adolescents who practice artistic gymnastic in elite and non-elite levels, and to analyze the influence of sociodemographic, anthropometric and maturational factors on body dissatisfaction. The research is characterized as transversal, quantitative, descriptive and correlational. The sample consisted of 285 adolescents, of both sexes, practicing gymnastics. They were divided into two groups: 245 non-elite athletes and 40 elite athletes. The participants were aged between 10 and 18 years (mean $12.86 \pm 1.80$ ) and were resident of the city of Três Rios-RJ. The assessment instruments were: Body Shape Questionnaire, Body Areas Scale, Critério de Classificação Econômica Brasil and socio-demographic questionnaire. Anthropometric and somatic maturation data were collected. The results showed that $24.9 \%$ of the non-elite athletes and $15 \%$ of elite athletes were dissatisfied with their body as a whole. For specific body areas, nonelite athletes were significantly more dissatisfied with their body area "weight" than the elite athletes. Sociodemographic and economic factors had no influence on overall body dissatisfaction. For non-elite athletes, only the body percentage of fat and somatic maturation were predictors for the overall body dissatisfaction and in specific areas, respectively. It was concluded that the non-elite athletes were more dissatisfied with their body and weight than the elite athletes.
\end{abstract}

KeY WoRDS: Body image; Gymnastics; Adolescents; Anthropometry.

\section{Introduction}

Body image has been valued as the focus of scientific research, especially since the $1990 \mathrm{~s}^{1}$. Authors agree that this construct is complex and multifaceted ${ }^{2-3}$. Furthermore, it involves the image that the individual has from the size, shape and contour of his own body as well as the feelings, thoughts and behaviors in relation to these characteristics ${ }^{2-3}$.

Currently, research on body image have privileged the evaluation of body dissatisfaction, mainly in samples of adolescents ${ }^{4-6}$. Understood as the negative and subjective evaluation of the own body ${ }^{2}$, body dissatisfaction can occur in several ways. Authors report that the individual can both be dissatisfied with their overall physical appearance ${ }^{4}$, and with some specific body parts ${ }^{5,7}$. In addition, some studies highlight that body dissatisfaction may be influenced by several factors such as: ethnicity ${ }^{8-9}$, socioeconomic level ${ }^{8,10}$, as well as social and cultural factors ${ }^{2}$.

Thus, the environment in which the subject is inserted can directly influence your body image. In this context, the sports environment - and in particular the modalities which value the aesthetic body - can be a way of higher sociocultural pressure motivated by the thin ideal body ${ }^{11-18}$. The artistic gymnastics may be cited as an environment in which these relationships are very present, because it implies a certain specific aesthetic body, by the requirement of a favorable biotype for practice ${ }^{17,19}$, which can lead athletes of this modality to a deep discontent with their own body.

Therefore, the sterotype body with short stature and low body fat is recommended in artistic gymnastics, because the ability to perform spins in 
different axes of the body is required constantly in the elements of this sport ${ }^{19-21}$. For this reason, artistic gymnastics is often cited as a modality that causes the emergence of specific characteristics of these athletes, such as the commitment of the growth in stature ${ }^{19,21}$. Regarding the high performance training, there are speculations that if this is intense and demanding, especially in childhood and adolescence may impair the growth ${ }^{19}$. However, a review study performed by Malina et al. ${ }^{20}$ point out that the stature reached in adulthood gymnastics athletes for both sexes is not compromised by training at young ages or during the peak growth spurt.

Recent studies evaluating anthropometric and maturation measures in athletes from various sports have found associations between these factors and negative body image ${ }^{22-23}$. In addition, the review study conducted by Neves et al. ${ }^{24}$ identified that

\section{Method}

\section{Ethical aspects}

This study was approved by the Ethics and Human Research Committee of the Federal University of Juiz de Fora (UFJF), according to the protocol 14406513.9.0000.5147 and approval number 337.127. All athletes and their guardians signed an informed consent form that explained the study objectives and procedures.

\section{Study design}

This is considered a cross-sectional, quantitative, descriptive and correlational study ${ }^{27}$. It was realized at the Artistic Gymnastics Training Center of Três Rios - RJ. By the year 2013 (date of the present study), the project was considered as a national reference center for this sport because it received elite athletes who representing Brazil in national and international competitions.

\section{Participants}

To calculate the sample size, it considered all the students enrolled in this project, aged between 10 and 18 years old in 2013. The prevalence of body dissatisfaction adopted for sample calculation was $31.9 \%$ - average values found in Brazilian studies with similar populations ${ }^{11,16,18}$. Adopting 95\% confidence few Brazilian research ${ }^{16,25-26}$ which considered the specifics of artistic gymnastics noted the influence of psychological factors such as media influence ${ }^{25}$, anxiety $^{26}$, perfectionism and $\operatorname{mood}^{16}$, on the eating disorder risk behavior of these athletes. However, the authors did not take into account the maturational factors and they disregarded the competitive level of individuals, which may influence the magnitude of these relationships. Therefore, we emphasize the importance of assessing body dissatisfaction in artistic gymnastics athletes both in the non-elite and elite levels, and relate it to sociodemographic, anthropometric and maturational factors.

This study aimed to evaluate the existence of overall and specific body dissatisfaction in elite and non-elite artistic gymnastics athletes, and to analyze the influence of sociodemographic, anthropometric and maturational factors on body dissatisfaction.

level and $5 \%$ of maximum error of estimation, it reached an ideal sample of 100 athletes, which is the minimum to obtain a representative sample of the present study population. To preserve the sample as representative of the population, it was decided to collect as much data as possible, overcoming the sample calculation.

The study included all athletes who were enrolled and regularly attending classes in Artistic Gymnastics Training Center of Três Rios - RJ during the data collection phase; who submit the signed informed consent; who could read and write; and those available to answer the questionnaires and conduct anthropometric assessments. Individuals who did not participate in any stage of data collection or did not complete the questionnaire in its entirety were excluded.

It is also worth mentioning that the study sample was divided into two groups: elite and non-elite athletes. According to Malina et al. ${ }^{20}$, the artistic gymnastics elite athletes training an average of 30 hours per week. This criterion was used as the cutoff point for the separation of sample groups in this study.

\section{Measures}

Initially, athletes answered a sociodemographic questionnaire, to access data such as age; ethnicity; education; and physical activity data (frequency and hours of weekly training). 
To identify the socioeconomic level, it was used the "Critério de Classificação Econômica Brasil' (CCEB) ${ }^{28}$. This instrument uses a survey of household characteristics (presence and quantity of some household items of comfort and education degree of the household head) to differentiate the population. The criterion function assigns points for each characteristic and performs the sum of the scores ranging from 0 to 46 . The rating is given from strata who follow the cutoffs: A1 - 42 to 46 points; A2 - 35 to 41 ; B1 - 29 to 34 ; B2 - 23 to 28 ; $\mathrm{C} 1-18$ to $22 ; \mathrm{C} 2-14$ to $17 ; \mathrm{D}-8$ to $13 ; \mathrm{E}-0$ to 7 .

To assess the dissatisfaction and concerns about body shape was used the Body Shape Questionnaire (BSQ), in its version validated for Brazilian adolescents $^{4}$. The instrument consists of 34 items in the Likert scale form of points, ranging from 1 (never) to 6 (always). The final score is the sum of the items and can range from 34 to 204. The BSQ classifies four levels of body dissatisfaction, as follows: score $<80$ points $=$ free of body dissatisfaction; score between 80 and $110=$ low body dissatisfaction; score between 110 and $140=$ moderate body dissatisfaction; and scores above $140=$ severe body dissatisfaction. For the present study sample, the instrument showed good internal consistency [Cronbach's alpha coefficient $(\alpha)=0.92]$.

To assess dissatisfaction with weight and with some specific body parts, it was used the Body Areas Scale (BAS) to adolescents 5 . The validated version among adolescents consists of 24 items, each corresponding to a body part. The level of satisfaction is accessed from a scale in Likert form of points from 1 (very satisfied) to 5 (very dissatisfied). The final score is given by the sum of scores of each item that can vary between 24 to 120 points. Higher score indicates greater body dissatisfaction. The instrument showed good internal consistency $(\alpha=0.90)$ for this sample.

In addition, we collected anthropometric data of body weight, height, trunk-cephalic height and skinfold (triceps and subscapularis). For these measures the described procedures were adopted by the International Society for the Advancement of Kineanthropometry (ISAK ${ }^{29}$. The body weight was measured using a portable digital scale Tanita with an accuracy of 100 grams and a maximum capacity of $200 \mathrm{~kg}$. The height was assessed using a portable stadiometer of Welmy, with accuracy of $0.5 \mathrm{~cm}$ and a maximum of $2.20 \mathrm{~m}$ capacity. The trunk-cephalic height was measured by LoHman ${ }^{30}$ bench. The skinfold thickness were measured using a compass LANGE with accuracy of $1 \mathrm{~mm}$ and $67 \mathrm{~mm}$ capacity.
The Body Mass Index (BMI) was calculated from the body weight and height $\left(\mathrm{kg} / \mathrm{m}^{2}\right)$, followed by age classifications recommended by the World Health Organization ${ }^{31}$. To estimate the percentage of body fat, it used the SLAUGHTER et al. ${ }^{32}$ protocol for adolescents.

To assess somatic maturation, we used the method developed by MiRwaLd et al. ${ }^{30}$ which consider the peak of height growth velocity. Height, body mass, trunk-cephalic height, leg length (difference between trunk-cephalic height and height) and chronological age data are required to estimate it. The combination of these values, from the formulas developed by authors $^{30}$, provide results with negative or positive scores. So, adolescents are classified as follows: score $<-1=$ Pre-spurt of growth in stature; score between -1 and $+1=$ During spurt of growth in stature; score $>+1=$ Post-spurt of growth in stature.

\section{Procedures}

Initially, the coordinator of the Artistic Gymnastics Training Center of Três Rios - RJ was contact to explain the objectives and the methods of the study, and request authorization to carry out the study. After the consent of coordination, the best days and times for the data collection were established.

At the time of data collection, a brief explanation of the objectives and the methods of the study was given for athletes and their guardians. The procedures were performed only after the informed consent form signature. Data collection happened between the months of October and December of 2013.

\section{Statistical analysis}

Regarding the analysis for nominal data, it was decided by the description in absolute and relative frequency, whereas for the numerical data analysis, the average and standard deviations were conducted. To analyze the internal consistency of the instruments BSQ and BAS we used the Cronbach's alpha coefficient, considering value above 0.70 as appropriate ${ }^{33}$. Then, the null hypothesis was confirmed, followed by parametric tests. The Student $t$ test was performed to evaluate differences of the means (age, \%BF, BMI, maturation, BSQ and BAS) between groups (elite and non-elite athletes). Pearson correlation test was performed to verify the association between the study variables (BSQ, BAS, BMI, \%BF, maturation and socioeconomic status), considering the groups elite and non-elite athletes separately. Then, forward linear regression was realized to determine 
the influence of the variables (significantly related) exerted on the overall body dissatisfaction (BSQ), and in specific body parts (BAS). The latter analysis was performed only for non-elite athletes, because on elite athletes group, the correlation test showed no statistically significant associations with the BSQ and the BAS. In all cases the level of significance was set at $\mathrm{p}<0.05$. The software used was SPSS 19.0.

\section{Results}

The study included 323 artistic gymnastics athletes of both sexes, in the city of Três Rios - RJ. However, 38 were excluded due to incomplete data. Thus, the total number of analyzed athletes was 285 . Of these, 40 adolescents met the criteria to be considered elite athletes. TABLES 1 and 2 shows, respectively, the description of the sample regarding sociodemographic (sex, ethnicity, and socioeconomic status) and physical (nutritional status, \%BF and somatic maturation) variables of elite and non-elite athletes.

TABLE 1 - Socio-demographic characteristics of the samples.

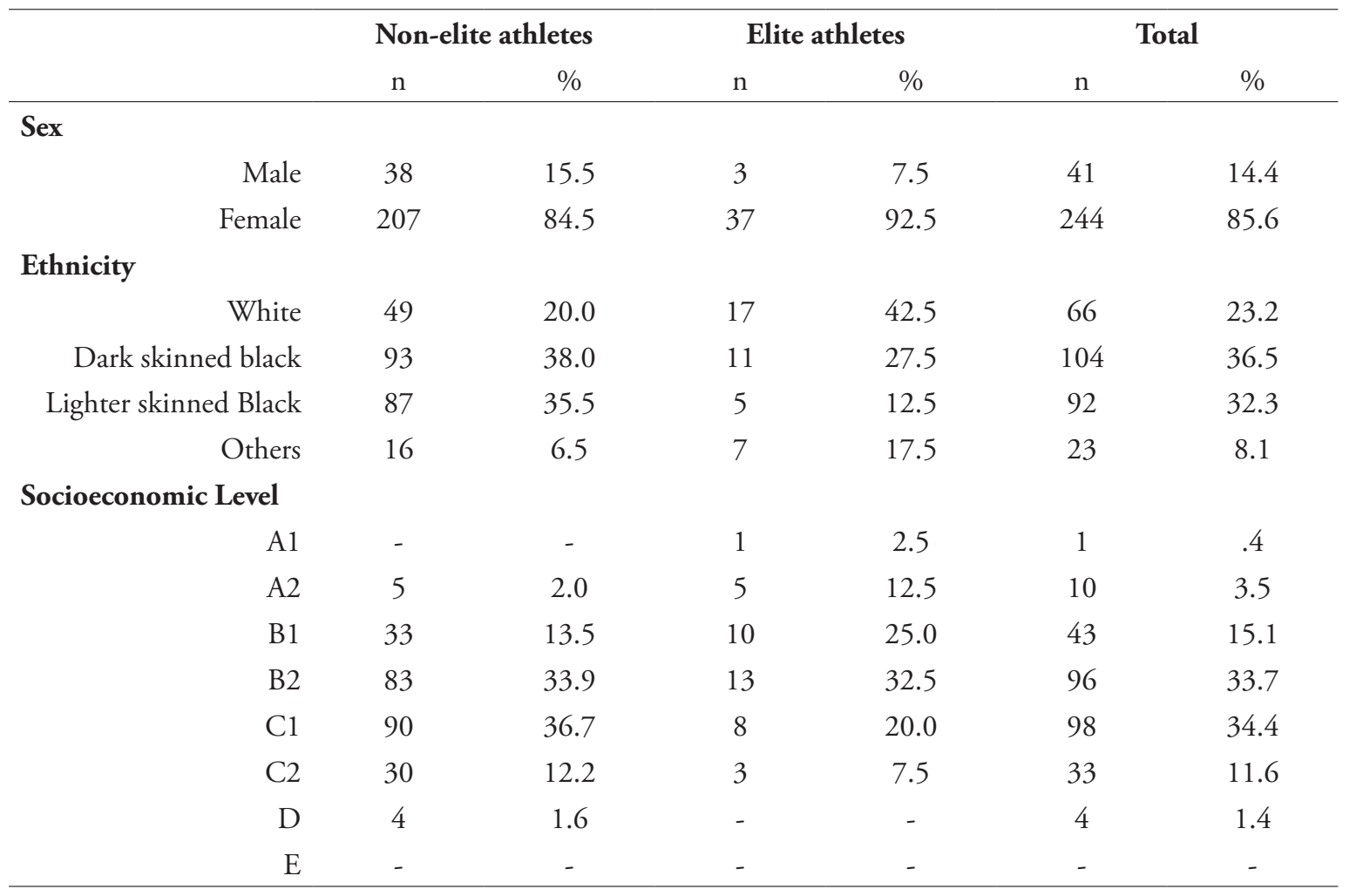


TABLE 2 - Physical characteristics of the athletes.

\begin{tabular}{|c|c|c|c|c|c|c|}
\hline & \multicolumn{2}{|c|}{ Non-elite athletes } & \multicolumn{2}{|c|}{ Elite athletes } & \multicolumn{2}{|c|}{ Total } \\
\hline & $\mathrm{n}$ & $\%$ & $\mathrm{n}$ & $\%$ & $\mathrm{n}$ & $\%$ \\
\hline \multicolumn{7}{|l|}{ Nutricional Status } \\
\hline Low weigth & 16 & 6.5 & 3 & 7.5 & 19 & 6.7 \\
\hline Normal weight (eutrophia) & 206 & 84.1 & 37 & 92.5 & 243 & 85.3 \\
\hline Overweight & 15 & 6.1 & - & - & 15 & 5.3 \\
\hline Obese & 8 & 3.3 & - & - & 8 & 2.8 \\
\hline \multicolumn{7}{|l|}{$\%$ BF } \\
\hline Low & 20 & 8.2 & 31 & 77.5 & 51 & 17.9 \\
\hline Normal & 107 & 43.7 & 9 & 22.5 & 116 & 40.7 \\
\hline High & 118 & 48.2 & - & - & 118 & 41.4 \\
\hline \multicolumn{7}{|l|}{ Peak Height Growth Velocity } \\
\hline Pre-spurt of growth in stature & 180 & 73.5 & 31 & 77.5 & 211 & 74.0 \\
\hline During spurt of growth in stature & 62 & 25.3 & 9 & 22.5 & 71 & 24.9 \\
\hline Post-spurt of growth in stature & 3 & 1.2 & - & - & 3 & 1.1 \\
\hline
\end{tabular}

Regarding the overall body dissatisfaction, assessed by BSQ, it was identified that $24.9 \%$ and $15 \%$ of the non-elite and elite athletes, respectively, had some level of dissatisfaction with the body (low, moderate or severe dissatisfaction). With respect to body dissatisfaction of specific areas evaluated by BAS, for the group of non-elite athletes, body areas that had higher average were: the "weight" $(2.33 \pm$ $1.45)$ followed by the "height" $(1.83 \pm 1.23)$. As for elite athletes, the "height" had higher average
$(2.00 \pm 1.15)$ followed by the "weight" $(1.93 \pm 1.07)$ (complete data not shown). The Student t test showed a significant difference only for body area "weight" ( $p$ $=0.038$ ), and the non-elite athletes had lower average.

TABLE 3 presents the descriptive analysis (mean and standard deviation) of age, socioeconomic status, BMI, \% BF, maturation, BSQ and BAS variables. Moreover, it shows the results of the comparison of means between groups (elite and non-elite athletes).

TABLE 3 - Descriptive analysis of the variables studied.

\begin{tabular}{lcccccc}
\hline & \multicolumn{2}{c}{ Non-elite athletes } & \multicolumn{2}{c}{ Elite athletes } & & \\
& Average & SD & Average & SD & t & p-valor \\
\hline Age (years old) & 12.57 & 1.87 & 13.33 & 1.86 & -2.41 & $0.017^{*}$ \\
CCEB & 23.10 & 5.27 & 27.05 & 6.71 & -3.552 & $0.001^{*}$ \\
BMI $\left(\mathrm{kg} / \mathrm{m}^{2}\right)$ & 19.34 & 3.28 & 18.15 & 2.11 & 3.004 & $0.004^{*}$ \\
$\%$ BF & 25.06 & 9.08 & 11.69 & 4.37 & 14.813 & $0.0001^{*}$ \\
Maturation & -1.81 & 1.26 & -1.72 & 1.19 & -0.404 & 0.687 \\
BSQ & 66.16 & 25.81 & 65.18 & 24.34 & 0.225 & 0.822 \\
BAS & 38.24 & 13.00 & 38.03 & 16.45 & 0.094 & 0.926 \\
\hline
\end{tabular}

SD: Standard Deviation; CCEB: Critério de Classificação Econômica Brasil; BMl: Body Mass Index; $\%$ BF: Body Percentage of Fat;

BSQ: Body Shape Questionnaire;

BAS: Body Area Scale; * significant at $p<0.05$
TABLE 4 shows the values obtained through the Pearson correlation test. Values above the diagonal line refer to elite athletes, while those below refer to non-elite athlete.

From the associations shown above for elite athletes, the regression analysis is not justified, because no variable was statistically associated with the BSQ and the BAS. For the group of non-elite athletes, there were two forward multiple linear regression analyzes, with the BSQ and BAS scores as criterion variable. In the first analysis (BSQ), the \%BF was inserted in block 1 (by having highest correlation value) and $\mathrm{BMI}$ in the block 2. The $\% \mathrm{BF}$ was responsible for $9.1 \%$ of the variance of the $B S Q$ scores $(F=25.440 ; p=0.001)$. The BMI did not add explain to the model, and therefore was deleted at the end of regression. 
In the second analysis (BAS), we inserted (by order of the correlation value): somatic maturation in block 1; age in block 2; BMI in block 3; and \%BF in block 4. Somatic maturation was responsible for $5.0 \%$ of the variance of the BAS scores $(\mathrm{F}=$ 13.949; $\mathrm{p}=0.001)$. The other variables did not add explanation to the model and therefore did not enter the final regression model.

TABLE 4 - Association between the study variables through the Pearson test (r).

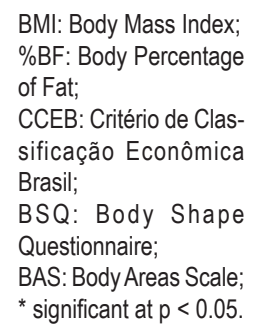

\begin{tabular}{lccccccc}
\hline Variables & Idade & BMI & Maturation & \%BF & CCBE & BSQ & BAS \\
\hline Age & - & $0.64^{*}$ & $0.97^{*}$ & $0.51^{*}$ & 0.19 & 0.04 & 0.19 \\
BMI & $0.37^{*}$ & - & $0.64^{*}$ & $0.70^{*}$ & 0.19 & 0.26 & 0.24 \\
Maturation & $0.94^{*}$ & $0.28^{*}$ & - & $0.55^{*}$ & 0.19 & 0.04 & 0.14 \\
\%BF & $0.22^{*}$ & $0.83^{*}$ & $0.14^{*}$ & - & -0.01 & 0.16 & 0.03 \\
CCBE & -0.02 & 0.04 & -0.04 & 0.07 & - & 0.18 & 0.22 \\
BSQ & 0.09 & $0.26^{*}$ & 0.07 & $0.31^{*}$ & 0.01 & - & $0.70^{*}$ \\
BAS & $0.23^{*}$ & $0.14^{*}$ & $0.23^{*}$ & $0.13^{*}$ & 0.03 & $0.43^{*}$ & - \\
\hline
\end{tabular}

\section{Discussion}

This study aimed to evaluate the existence of overall and specific body dissatisfaction in elite and non-elite artistic gymnastics athletes, and to analyze the influence of sociodemographic, anthropometric and maturation factors on body dissatisfaction. Some authors highlight that aesthetic sports athletes who practice dietary restrictions due to concern about weight may have income decrease in performance ${ }^{11,16}$. Therefore, we emphasize the importance of assessing body dissatisfaction in artistic gymnastics athletes, as it is a risk factor for developing eating disorders and it is directly related to food restriction ${ }^{34}$. Screening measures may help preventive actions to psychological health of these athletes.

The findings indicated that $24.9 \%$ and $15 \%$ of the non-elite and elite athletes, respectively, had some level of overall body dissatisfaction. These prevalence confirm data found by some Brazilian researchers who used the same instrument (BSQ) in aesthetic sports athletes. Neves et al. ${ }^{16}$ identified $25 \%$ of gymnastics athletes with body dissatisfaction considering girls who trained 15 hours per week. ForTes et al. ${ }^{11}$ found prevalence of $39 \%$ of body dissatisfaction in athletes of different aesthetic modalities that trained 10 hours per week. Study conducted by VIeIra et al. ${ }^{18}$, classified as rhythmic gymnastics athletes those who participated in two state-level competitions, and found that $31.7 \%$ were dissatisfied with their bodies. Another possibility is the division by age category, as in the study of Perini et al. ${ }^{35}$ which found $31.7 \%$ and $62.5 \%$ of body dissatisfaction in juniors and seniors synchronized swimming athletes, respectively.

Thus, among the national studies, it was found that there is no standard for the classification as elite and non-elite athletes. This research adopted the cutoff point of 30 hours of weekly training, as pointed out by review study conducted by MaLina et al. ${ }^{20}$. Also, this is a criterion that fits the reality of the Artistic Gymnastics Training Center of Três Rios - RJ. The current study identified a lower percentage of body dissatisfaction in the group of elite athletes. Thus, it is necessary to consider the athlete category to evaluation of body dissatisfaction.

With regard to body dissatisfaction of specific areas, few national surveys conducted this assessment. Research by Conti et al. ${ }^{7}$, in adolescents about the same age of those in the present study, found that both boys and girls reported dissatisfaction with stomach area and body weight. Similarly, our study identifies greater average of weight and height in both groups. This indicates that the athletes participating in the study are more dissatisfied with these areas. However, once again, the non-elite athletes showed greater dissatisfaction with their weight when compared to elite athletes.

One possible explanation for these findings is that elite athletes had significantly lower BMI and \%BF (TABLE 3). In addition to a natural selection of sports which looks for individuals with these characteristics ${ }^{17,19}$, the intensity of elite training helps these athletes present lower BMI and 
$\% \mathrm{BF}$. Thus, despite the competitive environment bring greater pressure in search of an aesthetic body considered socially perfect, intense training "models" the body so that the physical development of elite athletes resembles the ideal body standard valued in society (thinness) ${ }^{1}$.

Added to this, the results of association between anthropometric data and body dissatisfaction (TABLE 4) show that the groups are different. $\mathrm{BMI}$ and \%BF were associated with BSQ only for non-elite athletes and are not significant to elite athletes. To present sample, the body dissatisfaction of the elite athletes is not necessarily associated with anthropometric data. Therefore, the regression analysis was not recommended. It is possible that body dissatisfaction observed in elite athletes is the result of other influences, such as psychological variables, such as perfectionism, mood, eating behavior and media influence.

For non-elite athletes, it is important to note that $\mathrm{BMI}$ and \%BF showed high significant association $(\mathrm{r}=0.83)^{33}$. Furthermore, the two variables were relevant in body dissatisfaction (BSQ) confirming the literature ${ }^{7,35}$. However, through the regression analysis, only $\% \mathrm{BF}$ had an impact on the variance of the BSQ. Possibly, the BMI not added explanation to the model, because for athletes $\% \mathrm{BF}$ is considered a more appropriate ${ }^{22,36-37}$.

The results of multiple linear regression using the BAS as criterion variable indicated that only the somatic maturation modulated $5 \%$ of the variation in body dissatisfaction of specific areas. Study by Conti et al. ${ }^{7}$ assessed a group of nonathletes of similar age to the present study, with similar questionnaire, found an association between overweight and dissatisfaction in different body areas. This finding has not been confirmed on nonelite athletes because the BMI was excluded from the regression model. It appears that approximately $95 \%$ of dissatisfaction with different body areas can be explained by other factors.

Finally, another important result need to be highlighted: despite the age was statistically different between groups, the somatic maturation did not follow such a relationship. That is, although the elite athletes were older, their maturation stage was similar to that of the non-elite athletes. It seems that, for the evaluated athletes, the training intensity delayed the growth spurt. These findings are still controversial in the literature, because while NunOMUrA ${ }^{19}$ highlights the commitment of growth in stature with intense training, MaLina et al. ${ }^{20}$ claim that the height reached in adulthood for athletes is not compromised by the practice of artistic gymnastics. It is noteworthy that are recent studies that investigated the association of maturation with body dissatisfaction in athletes ${ }^{23,38-39}$ and, therefore, are still encouraged future research in the area.

Despite the relevant data found in this research, some limiting factors are worth mentioning. Firstly, the cross-section design makes it impossible to check relationship of cause and effect. In addition, in the case of adolescent athletes, the use of self-report instruments can be questioned, because they may not respond reliably, fearing cuts in staff. However, these methods have been widely used in similar samples ${ }^{11,16,18,35}$.

We suggest future studies in artistic gymnastics athletes to consider other factors involved in body dissatisfaction, such as perfectionism, mood, eating behavior and media influence. This suggestion has hypothesized the fact that body dissatisfaction of artistic gymnastics elite athletes has another motivator than the anthropometric and maturational factors evaluated in this study. Furthermore, assessment of a group of non-athletes could help in understanding the process of the appearance of the body dissatisfaction in non-elite athletes.

We concluded that the non-elite athletes were more dissatisfied with their body and weight than the elite athletes. This was identified by the instrument that assesses the overall body dissatisfaction, as well as the questionnaire that verifies specific questions related to the body areas. In addition, in non-elite athletes, only the $\% \mathrm{BF}$ and somatic maturation were predictors for overall and specific body dissatisfaction, respectively.

The evaluation of body image in sports should be encouraged as it can prevent the onset or development of psychological disorders such as eating disorders. 


\section{Resumo}

Insatisfação corporal e fatores sociodemográficos, antropométricos e maturacionais de atletas de ginástica artística

Este estudo buscou avaliar a insatisfação corporal geral e em áreas corporais específicas em adolescentes que praticam ginástica artística nos níveis de base e de alto rendimento, bem como analisar a influência de fatores sociodemográficos, antropométricos e maturacionais sobre a insatisfação corporal. A pesquisa é caracterizada como transversal, quantitativa, descritiva e correlacional. A amostra foi constituída por 285 adolescentes de ambos os sexos praticantes de ginástica artística. Eles foram divididos em dois grupos: 245 atletas da categoria de base e 40 atletas de alto rendimento. Os jovens tinham idade entre 10 e 18 anos (média de 12,86 $\pm 1,80$ ) e residiam na cidade de Três Rios-RJ. Os instrumentos utilizados para avaliação foram: Body Shape Questionnaire, Escala por Áreas Corporais, Critério de Classificação Econômica Brasil e questionário sociodemográfico. Foram coletados dados antropométricos e de maturação somática. Os resultados mostraram que 24,9\% dos atletas de base e 15\% dos atletas de alto rendimento apresentavam insatisfação corporal geral. Para as áreas corporais específicas, os atletas de base foram significativamente mais insatisfeitos com a área corporal "peso" do que os atletas de alto rendimento. Variáveis sociodemográficas e econômicas não exerceram influência sobre a insatisfação corporal geral. Em atletas de base, apenas o percentual de gordura e a maturação somática foram preditores para a insatisfação corporal geral e específica, respectivamente. Conclui-se que os atletas de base apresentaram maior insatisfação com seu corpo e peso corporal do que os atletas de alto rendimento.

PALAVRAS-CHAVE: Imagem corporal; Ginástica; Adolescentes; Antropometria.

\section{References}

1. Ferreira MEC, Castro MR, Morgado FFR. Imagem corporal: reflexôes, diretrizes e práticas de pesquisa. Juiz de Fora: Editora UFJF; 2014.

2. Cash TF, Smolak L. Body image: a handbook of science, practice, and prevention. 2a ed. New York: Guilford Press; 2011.

3. Slade PD. What is body image? Behav Res Ther. 1994;32: 497-502.

4. Conti MA, Cordás TA, Latorre MRDO. A study of the validity and reliability of the Brazilian version of the Body Shape Questionnaire (BSQ) among adolescents. Rev Bras Saude Mater Infant. 2009;9:331-8.

5. Conti MA, Latorre MRDO, Hearst N, Segurado A. Adaptaçáo transcultural, validaçáo e confiabilidade da Body Area Scale para adolescentes brasileiros. Cad Saúde Pública. 2009;25:2179-86.

6. Miranda VPN, Conti MA, Bastos R, Ferreira MEC. Insatisfação corporal em adolescentes brasileiros de municípios de pequeno porte de minas gerais. J Bras Psiquiatr. 2011;60:190-7.

7. Conti MA, Frutuoso MFP, Gambardella AMD. Excesso de peso e insatisfação corporal em adolescentes. Rev Nutr. 2005;18:491-7.

8. Fortes LS, Oliveira FG, Ferreira MEC. Influência de fatores afetivos, antropométricos e sociodemográficos sobre o comportamento alimentar em jovens atletas. J Bras Psiquiatr. 2012;61:148-53.

9. Sampei MA, Sigulem DM, Novo NF, Juliano Y, Colugnati FAB. Atitudes alimentares e imagem corporal em meninas adolescentes de ascendência nipônica e caucasiana em São Paulo (SP). J Pediatr. 2009;85:122-8.

10. Dunker KLL, Fernandes CPB, Carreira Filho D. Influência do nível socioeconômico sobre comportamentos de risco para transtornos alimentares em adolescentes. J Bras Psiquiatr. 2009;58:156-61.

11. Fortes LS, Neves CM, Filgueiras JF, Almeida SS, Ferreira MEC. Insatisfaçáo corporal, comprometimento psicológico ao exercício e comportamento alimentar em jovens atletas de esportes estéticos. Rev Bras Cineantropom Desempenho Hum. 2013;15:695-704.

12. Francisco R, Alarcão M, Narciso I. Aesthetic sports as high-risk contexts for eating disorders: young elite dancers and gymnasts perspectives. Span J Psychol. 2012;15:265-74.

13. Haas AN, Garcia ACD, Bertoletti J. Imagem corporal e bailarinas profissionais. Rev Bras Med Esporte. 2010;16: 182-5.

68 • Rev Bras Educ Fís Esporte, (São Paulo) 2016 Jan-Mar; 30(1):61-70 
14. Klinkowski N, Korte A, Pfeiffer E, Lehmkuhl U, Salbach-Andrae H. Psychopathology in elite rhythmic gymnasts and anorexia nervosa patients. Eur Child Adolesc Psychiatry. 2008;17:108-13.

15. Lepage ML, Crowther JH. The effects of exercise on body satisfaction and affect. Body Image. 2010;7:124-30.

16. Neves CM, Fortes LS, Filgueiras JF, Ferreira MEC. Comportamentos alimentares em ginastas de elite: associação com o perfeccionismo e o estado de humor. Rev Educ Fis/UEM. 2013;24:359-69.

17. Petrie TA, Greenleaf C. Body image and athleticism. In: Cash TF, Smolak L, editors. Body image: a handbook of science, practice, and prevention. 2nd ed. New York: Guilford Press; 2011. p. 67-75.

18. Vieira JLL, Vieira LF, Amorim HZ, Rocha PGM. Distúrbios de atitudes alimentares e sua relação com o crescimento físico de atletas paranaenses de ginástica rítmica. Motriz. 2009;15:552-61.

19. Nunomura M. Ginástica artística. São Paulo: Odysseus; 2008.

20. Malina RM, Baxter-Jones AD, Armstrong N, et al. Role of intensive training in the growth and maturation of artistic gymnasts. Sports Med. 2013;43:783-802.

21. Tsukamoto MHC, Nunomura M. Iniciação esportiva e infância: um olhar sobre a ginástica artística. Rev Bras Cienc Esporte. 2005;26:159-76.

22. Fortes LS, Almeida SS, Ferreira MEC. Impacto de variáveis antropométricas sobre a insatisfação corporal e o comportamento alimentar em jovens atletas. J Bras Psiquiatr. 2012;61:235-41.

23. Fortes LS, Almeida SS, Ferreira MEC. Processo maturacional, insatisfaçáo corporal e comportamento alimentar inadequado em jovens atletas. Rev Nutr. 2012;25:575-86.

24. Neves CM, Meireles JFF, Carvalho PHB, Ferreira MEC. Insatisfação corporal e comportamento alimentar em atletas de esportes estéticos: uma revisão. Pensar Prát. 2015;18:922-36.

25. Fortes LS, Almeida SS, Ferreira MEC. A internalização do ideal de magreza afeta os comportamentos alimentares inadequados em atletas do sexo feminino da ginástica artística? Rev Educ Fis/UEM. 2014;25:181-91.

26. Fortes LS, Almeida SS, Ferreira MEC. Influência da ansiedade nos comportamentos de risco para os transtornos alimentares em ginastas. Rev Bras Ativ Fis Saúde. 2013;18:546-53.

27. Thomas JR, Nelson JK, Silverman SJ. Métodos de pesquisa em atividade física. 5a ed. Sáo Paulo: Artmed; 2012.

28. Associação Brasileira de Empresas de Pesquisa. Critério de classificação econômica Brasil 2012. São Paulo: ABEP; 2012. [citado 7 dez. 2012]. Disponível em: http://www.abep.org/criterioBrasil.aspx.

29. Stewart A, Marfell-Jones M, Olds T, Ridder H. International standards for anthropometric assessment: ISAK: Lower Hutt: International Society for the Advancement of Kinanthropometry; 2011.

30. Mirwald RL, Baxter-Jones AD, Bailey DA, Beunen GP. An assessment of maturity from anthropometric measurements. Med Sci Sports Exerc. 2002;34:689-94.

31. Onis M, Onyango AW, Borghi E, Siyam A, Nishida C, Siekmann J. Development of a WHO growth reference for school-aged children and adolescents. Bull World Health Organ. 2007;85:660-7.

32. Slaughter MH, Lohman TG, Boileau RA, et al. Skinfold equations for estimation of body fatness in children and youth. Hum Biol. 1988;60:709-23.

33. Hair Júnior JF, Black WC, Babin BJ, Anderson RE, Tatham RL. Análise multivariada de dados. 6a ed. São Paulo: Bookman; 2009.

34. American Psychiatric Association. Diagnostic and statistical manual of mental disorders (DSM-V). 5th ed. Washington: APA; 2014.

35. Perini TA, Vieira RS, Vigário PS, Oliveira GL, Ornellas JS, Oliveira FP. Transtorno do comportamento alimentar em atletas de elite de nado sincronizado. Rev Bras Med Esporte. 2009;15:54-7.

36. Fortes LS, Almeida SS, Ferreira MEC. Indicadores antropométricos de insatisfação corporal e de comportamentos alimentares inadequados em jovens atletas. Rev. Bras. Med. Esporte. 2013;19:35-9.

37. Tortveit MK, Sundgot-Borgen J. Are under- and overweight female elite athletes thin and fat? A controlled study. Med Sci Sports Exerc. 2012;44:949-57.

38. Fortes LS, Almeida SS, Ferreira MEC. Insatisfação corporal e maturação biológica em atletas do sexo masculino. Rev Bras Educ Fis Esporte. 2013;27;297-303.

39. Fortes LS, Conti MA, Ferreira MEC. Relação entre comportamentos de risco para transtornos alimentares e processo maturacional em jovens atletas. Rev Bras Ativ Fís Saúde. 2012;17:379-95. 
Neves CM, et al.

\section{Acknowledgments}

To the UFJF for granting the monitoring of scholarship (Master) to the first author.

Clara Mockdece

R. Belo Horizonte, 85, apto. 501

36016-430 - Juiz de Fora - MG - BRASIL

e-mail: clarinhamockdece@hotmail.com
Recebido para publicação: 13/10/2015

Aceito: $10 / 12 / 2015$

70 • Rev Bras Educ Fís Esporte, (São Paulo) 2016 Jan-Mar; 30(1):61-70 